\title{
Properties of Mine Soils in a Forested Hilly Terrain of South eastern Nigeria
}

\author{
E. U. Onweremadu ${ }^{1, ~ *}$, E. I. Uzor ${ }^{1}$, Egbuche C. T. $^{2}$, L. C. Agim ${ }^{1}$, D. J. Njoku ${ }^{3}$, A. C. Udebuani ${ }^{4}$ \\ ${ }^{1}$ Department of Soil Science and Technology, Federal University of Technology, Owerri Nigeria \\ ${ }^{2}$ Department of, Forestry and Wildlife Technology, Federal University of Technology, Owerri, Nigeria \\ ${ }^{3}$ Department of Environmental Technology, Federal University of Technology, Owerri, Nigeria \\ ${ }^{4}$ Department of Biotechnology, Federal University of Technology, Owerri, Nigeria
}

Email address:

uzomaonweremadu@yahoo.com (E. U. Onweremadu)

\section{To cite this article:}

E. U. Onweremadu, E. I. Uzor, Egbuche C. T., L. C. Agim, D. J. Njoku and A.C. Udebuani. Properties of Mine Soils in a Forested Hilly Terrain of Southeastern Nigeria. Agriculture, Forestry and Fisheries. Special Issue: Environment and Applied Science Management in a Changing Global Climate. Vol. 4, No. 3-1, 2015, pp. 34-39. doi: 10.11648/j.aff.s.2015040301.16

\begin{abstract}
Soils of a mine site at Leru, Abia State, Nigeria were characterized and classified for proper usage .A transect survey technique was employed in which a traverse was cut to link soils affected by mining to the unaffected soils in the area. Soil profile pits were dug described and sampled using standard techniques. Routine laboratory analyses were conducted on soil samples for selected soil properties. Soil data were subjected to mean statistic. Results indicated increasing sandiness and hulk densi1 in the epipedons closest to the mine site. Mean value of soil moisture in un-mined site (149.8 $\mathrm{g} \mathrm{kg}^{-1}$ ) was higher than those of mine soils (144.2 $\mathrm{g} \mathrm{kg}^{-1}$ for middle land unit and $137.0 \mathrm{~g} \mathrm{~kg}^{-1}$ for pedon closest to the mine site). Mine soils were younger with silt-clay ratio ranging from 3.7 to 7.0 while unaffected soils were older (silt-clay ratio $=0.6)$. Low values of calcium-magnesium ratios $(\mathrm{Ca} / \mathrm{Mg}<3.0)$ were reported. Soil $\mathrm{pH}$ progressively increased towards un-mined site. The soil profile proximal to the mine site was shallower (depth $<100 \mathrm{~cm}$ ) when compared with other soil profiles, and had a lithic contact at $90 \mathrm{~cm}$ depth. Based on field and laboratory analysis soils were classified as Lithic Dystrudepts ( 5 metres away from mine site), Typic Haplanthrepts (25 metres away from mine site) and Typic Hapludults (2 kilometres away from mine site).
\end{abstract}

Keywords: Classification, Degradation, Mining, Soils, Topography

\section{Introduction}

Mining activities disrupt partially or totally the original characteristics and qualities of soils and re-set the pace of soil formation. Mining influences soil physical and structural properties [1], disturbs farmland forests and waterways [2], increases water stable aggregates [3] and initiates differences in water stable aggregation among soil horizris [4]. Overburden in soils of mine sites influence soil texture, soil colour and soil subsurface $\mathrm{pH}$ [5]. [6] reported that unconsolidated materials resulting largely from landfills, mine soils. Rubble garbage dumps and dredging generate fresh anthropgeomorphic parent materials on which new soils develop. The nature of soils formed depends on the type of parent material [7]. Mined soils can have poor water retention resulting from high coarse fragment content, lack of fine earth, and poor soil structure which allow water to drain quickly from the soil profile [8]. High levels of soluble salts in minerals inhibit water and carbon dioxide uptake: and inactivate enzymes affecting protein synthesis. $\mathrm{C}$ metabolism and photophosphorylation [9]. Soil nitrogen, organic carbon and phosphorus have been reported as growth limiting factors on mined soils, especially within 10 years after disturbance. Organic matter and total nitrogen are used as good indicators of $\mathrm{N}$ availability in mine soils [10]. In southeastern Nigeria, there is an increasing demographic pressure on available soil resources [11] leading to soil stresses [12] (Reich et al., 2001) and land degradation [13] (Onweremadu, 2008; [14] Onweremadu et al.. 2010). Unprofitable agricultural enterprise has led to diversion of socio-economic activities towards non-agricultural ventures in Southeastern Nigeria. Because quick returns are obtained in milling rock minerals like coals, rocks and salts, it has become a major socioeconomic activity in Nigeria. These activities have 
attracted extractive and non-extractive industries such as quarrying industries, most of which do not consider the impact on the ecosystem despite the need for environmental quality control. At Leru in Umunneochi, Abia State Nigeria, sand and gravel mining coupled with quarrying are socioeconomically attractive, causing more native populations to engage in it. This study was therefore undertaken to characterize soil properties of the affected soils by these mining activities, and classify them using USDA soil Taxonomy.

\section{Materials and Methods}

\subsection{Study Area}

The study was conducted at Leru in Umunneochi Local Government Area in Abia State, Southeastern Nigeria. Leru mine lies between Latitudes $5^{\circ} 30^{\prime}$ and $6^{\circ} 08^{\prime} \mathrm{N}$, and Longitudes $7^{\circ} 20^{\prime}$ and $7^{\circ} 50^{\prime} \mathrm{E}$. The mine sites are sparsely populated and occupies over 5000 ha of farmland. The soils are derived from upper coal measures or Nsukka formation [15] and belong to the Eastern Nigeria highlands [16]. The area lies within the humid tropics, with a mean annual rainfall range of $2000-2250 \mathrm{~mm}$ and mean annual temperature ranging from $27-28{ }^{\circ} \mathrm{C}$ ' [17]. Leru has a rainforest vegetation which has been depleted b> anthropogenic activities such as agriculture, stone mining and quarrying. The rainforest is less dense compared with southern locations, but comprises varying levels and species of plants arranged in storey. Prominent plant species include oil palms (Elaeis guineensis), oil bean tree (Pentaclethra macrophyllum), maize (Zea mays), cashew (Anarcadium occidentale), cassava (Manihot esculenta), Pineapple (Ananas cornosus), yams (Dioscorea Species), and others. Mining of earth minerals and agriculture are the major socio-economic activities of the area.

\subsection{Field Sampling}

Transect soil survey technique guided field sampling. A transverse was cut to link three identified land units, namely soils 5 meters away from the mine site, soils 25 metres away from the mine site and soils $2 \mathrm{~km}$ away from the mine site, based on observed macro morphological changes.. Profile pits were dug in each land unit and described according to [18] procedure. Soil samples were collected based on the degree of soil horizon differentiation, thereafter, they were bagged and transported to the laboratory where they were air-dried and sieved using 2$\mathrm{mm}$ sieve preparatory to laboratory analyses. Core soil samples were collected for bulk density determinations from delineated horizons.

\subsection{Laboratory Analyses}

Particle size distribution was determined by hydrometer method [19] (Gee and Or. 2002). Bulk density was measured by core method [20] (Grossman and Reinsch.
2002). Total porosity was calculated as follows:

$$
\text { Total porosity }=100 \%-\left(\frac{\mathrm{BD}}{\mathrm{PD}} \times \frac{100}{1}\right)
$$

Where $\mathrm{BD}=$ bulk density

$\mathrm{PD}=$ particle density (assumed to be $2.65 \mathrm{Mg} / \mathrm{kg}$ )

Available water capacity was computed as the difference between the moisture retained at 0.10 and 15 bars tensions.

Soil $\mathrm{pH}$ was determined on a 1:1 soil/water sample [22]. Soil organic carbon (SOC) was estimated according to the procedure of [23]. Total nitrogen was determined by Kjedahl digestion [24]. Available phosphorus was obtained using Bray P No .2 method [25]. Exchangeable acidity was measure titrimetrically [26]. Exchangeable basic cations were extracted using IM N1-I1OAC, and exchangeable Ca and $\mathrm{Mg}$ were determined by EDTA titration, while $\mathrm{Na}$ and $\mathrm{K}$ were measured photometrically [27]. Elemental ratios of $\mathrm{CIN}$ and $\mathrm{Ca} / \mathrm{Mg}$ were computed to assess fertility of the mine soils.

\subsection{Data Analysis}

Soil data were analyzed using descriptive statistics: mean and statistical tests of difference were conducted using t-test at $5 \%$ level of significance between mine and natural soils.

\section{Results and Discussion}

\subsection{Macromorphological Properties}

Morphological properties of the soils are presented in Table 1. The Soils show thicker A-horizon nearest to the mine. Effective soil depth increased with increased distance from mine site while colors of A horizon became darker. Differences in soil thickness could be a result of human activities like spoil layering more than pedogenic processes. Soils 5 meters away from the mine site were redder (Reddish brown 5YR4/6) moist as opposed to darker colors (Dark reddish brown (YR3/2)) obtained from soils 2 kilometers away from the mine site at surface horizon. Color changes in horizons were likely a result of spoil layering. Removed strata during mining were transported sideways and downwards, giving rise to heterogeneity of soils in terms of soil morphological properties. Root development was improved in soils far away from the mine site. Granular structures predominate in soils distal to the mine site, indicating more pedogenic activities away from the mine site. However, the thicker A-horizon $(21 \mathrm{~cm})$ in soils closest (5-meters away) the mine site compared to non-mine site $(10 \mathrm{~cm})$ could provide greater volume of rooting zone for crops. In a similar study. [28] found that mine soils have deeper root zones, higher hulk densities and weaker soil structure compared with native soils. Greater thickness in A-horizon is attributable to high population of grasses near the mine. 
Table 1. Morphological Properties of the Mine Soils

\begin{tabular}{|c|c|c|c|c|c|c|c|c|}
\hline Horizon & Depth (cm) & Soil colour (moist) & Structure & & \multicolumn{2}{|l|}{ Consistence } & Boundary & Roots \\
\hline \multicolumn{9}{|c|}{5 meters away from mine site (Lithic Dystrudepts) } \\
\hline A & $0-21$ & $\begin{array}{l}\text { Reddish } \\
\text { Brown (5YR4/6) }\end{array}$ & $\begin{array}{l}\text { Weak } \\
\text { Subangular blocky }\end{array}$ & Fine & fr & & Cs & Many very fine roots \\
\hline $\mathrm{BC}$ & $21-68$ & $\begin{array}{l}\text { Reddish brown } \\
\text { (5YR4/8) }\end{array}$ & $\begin{array}{l}\text { Weak Subangular } \\
\text { block }\end{array}$ & Coarse & $\mathrm{f}$ & & d & $\begin{array}{l}\text { Few medium and large } \\
\text { roots }\end{array}$ \\
\hline $\mathrm{C}$ & $68-90$ & Orange (5YR 6/6) & Weak & Coarse & $\mathrm{fr}$ & & - & Very few large roots \\
\hline \multicolumn{9}{|c|}{25 meters away from mine site (Typic Haplanthrepts) } \\
\hline \multirow[t]{2}{*}{ A } & $0-11$ & $\begin{array}{l}\text { Reddish brown } \\
\text { (5YR4/8) }\end{array}$ & Moderate granular & Medium & vfr & & & Many vey fine roots \\
\hline & & & & & & & $\mathrm{C}$ & \\
\hline $\mathrm{Bw}_{1}$ & $11-49$ & $\begin{array}{l}\text { Bright reddish } \\
\text { brown (5YR 5/6) }\end{array}$ & Moderate & coarse & fi & $\mathrm{D}$ & & Many fine root \\
\hline $\mathrm{Bw}_{2}$ & $49-80$ & $\begin{array}{l}\text { Bright reddish brown } \\
\text { ( } 5 \text { YR 5/8) }\end{array}$ & $\begin{array}{l}\text { Moderate medium } \\
\text { subangular blocky }\end{array}$ & & vfi & $\mathrm{D}$ & & Many fine roots \\
\hline $2 \mathrm{E} / \mathrm{B}$ & $80-88$ & Orange $(6 / 6)$ & $\begin{array}{l}\text { Moderate course } \\
\text { subangular blocky }\end{array}$ & coarse & vfi & $\mathrm{D}$ & & Very few large roots \\
\hline $2 \mathrm{Btxb}$ & $88-120$ & Orange (5YR 9/8) & Moderate prismatic & Coarse & efi & - & & Very few large roots \\
\hline \multicolumn{9}{|c|}{2 Kilometers away from mine site (Typic Hapludults) } \\
\hline A & $0-10$ & $\begin{array}{l}\text { Dark reddish brown } \\
\text { (YR3/2) }\end{array}$ & Granular medium & & fr & Cs & & Many very fine root \\
\hline $\mathrm{E}$ & $10-26$ & $\begin{array}{l}\text { Light brown reddish } \\
\text { (YR6/4) }\end{array}$ & $\begin{array}{l}\text { Medium sub } \\
\text { angular blocky }\end{array}$ & & fi & $\mathrm{D}$ & & $\begin{array}{l}\text { Common fine and few } \\
\text { medium large root }\end{array}$ \\
\hline $\mathrm{Bt}_{1}$ & $26-65$ & $\begin{array}{l}\text { Yellowish red } \\
\text { (7YR4/4) }\end{array}$ & $\begin{array}{l}\text { Medium sub } \\
\text { angular blocky }\end{array}$ & & fi & $\mathrm{D}$ & & Few medium large root \\
\hline $\mathrm{Bt}_{2}$ & $65-120$ & $\begin{array}{l}\text { Yellowish red } \\
(7.5 \text { YR5/4) }\end{array}$ & $\begin{array}{l}\text { Medium subangular } \\
\text { blocky }\end{array}$ & Course & fi & $\mathrm{D}$ & & Few medium large root \\
\hline $\mathrm{BC}$ & $120-150$ & $\begin{array}{l}\text { Yellowish red } \\
(7.5 \text { YR6/6) }\end{array}$ & $\begin{array}{l}\text { Medium course sub } \\
\text { angular blocky }\end{array}$ & & $\mathrm{f}$ & - & & Very few large root \\
\hline
\end{tabular}

$\mathrm{fr}=$ friable, $\mathrm{fi}=$ firm, $\mathrm{vfr}=$ very friable, efi $=$ extremely firm $\mathrm{c}=$ clear, $\mathrm{s}=$ smooth, $\mathrm{D}=$ diffuse

Table 2. Selected physical properties of the soils

\begin{tabular}{|c|c|c|c|c|c|c|c|c|c|}
\hline Horizon & Depth cm & Total sand $\left(\mathrm{kg}^{-1}\right)$ & Silt $\left(\mathrm{g} \mathrm{kg}^{-1}\right)$ & Clay $\mathrm{g}_{\left(\mathrm{kg}^{-1}\right)}$ & SCR & Texture & $\mathrm{BD}\left(\mathrm{Mg} \mathrm{M}^{-3}\right)$ & $T P\left(\mathrm{~g} \mathrm{~kg}^{-1}\right)$ & $\operatorname{MC~} g\left(\mathrm{~kg}^{-1}\right)$ \\
\hline \multicolumn{10}{|c|}{5 meters away from mine site (Lithic Dystrudepts) } \\
\hline A & $0-21$ & 910 & 80 & 10 & 8.0 & $\mathrm{~S}$ & 1.40 & 47.2 & 133 \\
\hline Bw & $21-68$ & 890 & 100 & 10 & 10.0 & $\mathrm{~S}$ & 1.58 & 41.4 & 141 \\
\hline \multirow[t]{2}{*}{$\mathrm{C}$} & $68-90$ & 880 & 90 & 30 & 3.0 & $\mathrm{~S}$ & 1.67 & 36.9 & 41.37 \\
\hline & Mean & 893.3 & 90.0 & 16.7 & 7.0 & - & 1.53 & 42.6 & 137 \\
\hline \multicolumn{10}{|c|}{25 meters away from mine site (Typic Haplanthrepts) } \\
\hline A & $0-11$ & 890 & 100 & 10 & 10.0 & $\mathrm{~S}$ & 1.38 & 47.9 & 142 \\
\hline Bw1 & $11-49$ & 900 & 80 & 20 & 4.0 & $\mathrm{~S}$ & 1.50 & 43.3 & 145 \\
\hline Bw2 & $49-80$ & 880 & 80 & 40 & 2.0 & $\mathrm{~S}$ & 1.52 & 42.6 & 146 \\
\hline $2 \mathrm{E} / \mathrm{B}$ & $80-88$ & 860 & 100 & 40 & 2.5 & SL & 1.61 & 39.2 & 140 \\
\hline \multirow[t]{2}{*}{$2 \mathrm{Btxb}$} & & 820 & 30 & 150 & 0.2 & SL & 1.63 & 38.4 & 148 \\
\hline & Mean & 870 & 78 & 52 & 3.7 & - & 1.52 & 42.2 & 144.2 \\
\hline \multicolumn{10}{|c|}{2 kilometers meters away from mine site (Typic Haplanthrepts)) } \\
\hline A & $0-20$ & 855 & 50 & 100 & 0.5 & SL & 1.29 & 51.3 & 150 \\
\hline $\mathrm{E}$ & $20-26$ & 870 & 20 & 110 & 0.2 & SL & 1.35 & 49.1 & 125 \\
\hline Bt1 & $26-65$ & 850 & 10 & 140 & 0.1 & SL & 1.40 & 47.2 & 158 \\
\hline $\mathrm{Bt} 2$ & $65-120$ & 860 & 20 & 120 & 0.2 & SL & 1.42 & 46.4 & 155 \\
\hline \multirow[t]{2}{*}{$\mathrm{BC}$} & $120-150$ & 880 & 80 & 40 & 2.0 & LS & 1.56 & 41.1 & 141 \\
\hline & Mean & 862 & 36 & 102 & 0.6 & - & 1.40 & 47.0 & 149.8 \\
\hline
\end{tabular}

$\mathrm{S}=$ sand, $\mathrm{LS}=$ loamy sand, $\mathrm{SL}=$ sandy Loam $\mathrm{BD}=$ bulk density, $\mathrm{TP}=$ total porosity, $\mathrm{MC}=$ moisture content, $\mathrm{CV}=$ coefficient of variation, $\mathrm{SCR}=$ silt clay ratio, $\mathrm{G}$. mean= grand mean, $\mathrm{G} . \mathrm{CV}=$ grand coefficient of variation. 


\subsection{Soil Physical and Chemical Properties}

The soil physical properties (Table 2) indicate higher bulk densities ranging from $1.294 \mathrm{~g} \mathrm{M} 3$ in so that is $2 \mathrm{~km}$ away from mine area to $1.67 \mathrm{Mg} \mathrm{M} 3$ in soil that is 5 meters away from the site and lower total porosities in soils proximal to the mine with values ranging from 36.9 to $51.30 \mathrm{~g} / \mathrm{kg}$. This could he due to overburden effect and coarseness of the soils. It was reported that such soils do not retain enough water, possibly emanating from high sandiness [29]. Particle size distribution showed dominance of sand $(820910 \mathrm{~g} / \mathrm{kg})$ and silt (30 -100 g/ kg) over clay. The dominance of these two particle sizes over clay implies that crushing of parent materials and rock fragments genetically and sequentially produced sand, then silt, and these sizes are transformed into clay with intense weathering and pedogenesis. Very high siltclay ratios ranging from $8-10$ were obtained in soils closest to the mine site, indicating that they are young. [30] reported that mine soils show either some development (Inceptisols) or exhibits little or no development (Entisols).

The soil chemical properties are shown on Table 3, with soil acidity increasing towards the mine site. Higher acidity (5.6) of soils proximal to the mine site is a property probably inherited from the overburden parent materials, that are acidproducing. Even where these materials contain basic cations, they are easily leached due to high rainfall amount, intensity and duration characteristic of the study site leaving a preponderance of acidic cations. [31] reported that carbonates contained in overburden strata in mine sites are readily leached thereby creating an acid environment. It is possible that the oxidation potential of the parent materials counts in influencing $\mathrm{pH}$ of mine soils. [32], found that mine soils forming in partially oxidized sandstone overburden have an initial surface p1-1 of 5.5, whereas mine soils forming in unoxidized sandstone, and siltstone overburden had an initial $\mathrm{pH}$ of 7.5. There was no trend in the distribution of organic matter in a spatial orientation, although it decreased with depth in all the profiles. Highest values $23.12 \mathrm{~g} \mathrm{~kg}$ was recorded in soils, 25 meters away from the mine site. However, total nitrogen value were higher in native soils, implying that greater leaching predisposed by high acidity of mine soils may have affected their nitrogen content. Carbonnitrogen ratios (14.9) of native soils are close to values typical of West African soils with C/N 12-14. However, these values were very low in mine soils. It implies that $\mathrm{C} / \mathrm{N}$ ratios of mine soils have not stabilized to typical values in the West African biome. Calcium-magnesium ratio is an index of soil fertility [33], with values tying below 3.0 indicating poor fertility of soils in all land units. [34] suggested the use of calcium-aluminum ratios as a better indicator of calcium nutrition. The $\mathrm{Ca}: \mathrm{Mg}$ ratios below 3.0 lead to unavailability of calcium and available phosphorus [35].

The soils show low available phosphorus in soils closest to the mine site which is attributable to high acidity of the soils, and consequent fixation of phosphorus (Table 3). In some soils, calcium can he derived from rock fragments [36], but the rock fragments in this mine site are from sandstones, which are naturally acidic and calcium-poor. There were significant $(p=0.05)$ changes in the distribution of OM, TN, $\mathrm{C} / \mathrm{N}, \mathrm{Ca} / \mathrm{Mg}$, clay $\mathrm{SCR}$ and $\mathrm{MC}$ while non-significant differences were recorded in $\mathrm{BD}, \mathrm{pH}$ and Avail. $\mathrm{P}$ in the study site (Table 4).

Table 3. Selected chemical properties of the soils

\begin{tabular}{|c|c|c|c|c|c|c|c|c|}
\hline Horizon & Depth cm & pH water & OM g kg-1 & TN $\left(\right.$ gkg $\left.^{-1}\right)$ & SCR & Avail P mg kg & $\mathbf{C} / \mathbf{N}$ & $\mathrm{Ca} / \mathrm{Mg}$ \\
\hline & \multicolumn{8}{|c|}{5 meters away from mine site (Lithic Dystrudepts) } \\
\hline A & $0-21$ & 5.9 & 21.0 & 1.3 & 33.1 & $\mathrm{~S}$ & 5.3 & 0.90 \\
\hline $\mathrm{Bw}$ & $21-68$ & 5.4 & 20.9 & 1.0 & 26.1 & $\mathrm{~S}$ & 8.6 & 0.91 \\
\hline \multirow[t]{3}{*}{$\mathrm{C}$} & $68-90$ & 5.7 & 19.3 & 0.8 & 21.7 & $\mathrm{~S}$ & 14.0 & 0.92 \\
\hline & Mean & 5.6 & 20.3 & 0.6 & 27.1 & - & 9.3 & 0.91 \\
\hline & \multicolumn{8}{|c|}{25 meters away from mine site (Typic Haplanthrepts) } \\
\hline A & $0-11$ & 5.5 & 25.9 & 1.8 & 37.6 & $\mathrm{~S}$ & 3.9 & 0.91 \\
\hline Bw1 & $11-49$ & 5.8 & 23.6 & 1.7 & 28.9 & $\mathrm{~S}$ & 5.2 & 0.94 \\
\hline Bw2 & $49-80$ & 5.7 & 23.8 & 1.6 & 7.8 & $\mathrm{~S}$ & 7.2 & 0.94 . \\
\hline $2 \mathrm{E} / \mathrm{B}$ & $80-88$ & 5.7 & 24.2 & 1.1 & 15.9 & SL & 8.5 & 0.90 \\
\hline \multirow[t]{3}{*}{ 2Btxb } & & 5.7 & 18.1 & 0.9 & 13.2 & $\mathrm{SL}$ & 5.2 & 0.90 \\
\hline & Mean & 5.7 & 23.12 & 1.4 & 22.7 & - & 6.2 & 0.92 \\
\hline & \multicolumn{8}{|c|}{2 kilometers meters away from mine site (Typic Haplanthrepts) } \\
\hline A & $0-20$ & 6.6 & 24.3 & 2.3 & 46.4 & SL & 10.6 & 2.9 \\
\hline $\mathrm{E}$ & $20-26$ & 6.0 & 11.8 & 11.8 & 41.3 & $\mathrm{SL}$ & 11.9 & 2.0 \\
\hline Bt1 & $26-65$ & 6.2 & 9.2 & 9.2 & 40.6 & SL & 13.6 & 3.0 \\
\hline $\mathrm{Bt} 2$ & $65-120$ & 6.5 & 7.6 & 7.6 & 40.3 & SL & 14.9 & 1.8 \\
\hline \multirow[t]{2}{*}{$\mathrm{BC}$} & $120-150$ & 6.4 & 5.2 & 5.2 & 40.1 & LS & 12.0 & 1.6 \\
\hline & Mean & 6.3 & 11.6 & 11.6 & 41.7 & - & 12.6 & 2.3 \\
\hline
\end{tabular}

$\mathrm{S}=$ sand, $\mathrm{LS}=$ loamy sand, $\mathrm{SL}=$ sandy Loam, $\mathrm{BD}=$ bulk density, $\mathrm{TP}=$ total porosity, $\mathrm{MC}=$ moisture content, $\mathrm{CV}=$ coefficient of variation, $\mathrm{SCR}=$ silt clay ratio,

G. mean= grand mean, G. CV = grand coefficient of variation. 
Table 4. Statistical tests of difference for selected properties in mine and natural soils $(p=0.05)$.

\begin{tabular}{ll}
\hline Soil property & Calculated t-values \\
\hline $\mathrm{pH}$ water & $1.862^{\mathrm{NS}}$ \\
$\mathrm{OM}\left(\mathrm{g} \mathrm{kg}^{-1}\right)$ & $3.940^{*}$ \\
$\mathrm{TN}\left(\mathrm{g} \mathrm{kg}^{-1}\right)$ & $2.939^{*}$ \\
Avail. $\mathrm{P}\left(\mathrm{mg} \mathrm{kg}^{-1}\right)$ & $2.617^{\mathrm{NS}}$ \\
$\mathrm{C} / \mathrm{N}-$ & $2.739^{*}$ \\
$\mathrm{Ca} / \mathrm{Mg}-$ & $2.983^{*}$ \\
$\mathrm{SCR}-$ & $2.886^{*}$ \\
$\mathrm{Clay}\left(\left(\mathrm{g} \mathrm{kg}^{-1}\right)\right.$ & $3.623^{*}$ \\
$\mathrm{MC}\left(\mathrm{g} \mathrm{kg}^{-1}\right)$ & $2.932^{*}$ \\
B.D. $\left(\mathrm{Mg} \mathrm{m}^{-3}\right)$ & $0.768^{\mathrm{NS}}$ \\
\hline
\end{tabular}

$\mathrm{OM}=$ organic matter, $\mathrm{TN}=$ total nitrogen, Avail. $\mathrm{P}=$ available phosphorus, $\mathrm{C} / \mathrm{N}=$ carbon-nitrogen ratio, $\mathrm{Ca} / \mathrm{Mg}=$ calcium-magnesium 1 atio, $\mathrm{SCR}=$ siltclay ratio, $\mathrm{MC}=$ moisture content, $\mathrm{BD}=$ bulk density $*=$ significant at $5 \%$ level of probability, $\mathrm{NS}=$ not significant

\section{Conclusions}

The study revealed differences in some morphological and physiochemical soil properties among geographicallyassociated mine soil units. Soils closest to the mine site were least differentiated based on distinctness of soil horizons while most distal soils exhibited pronounced soil formation as indicated by Bt (argillic) horizon. Bulk density and moisture content decreased away from the mine site. Soil $\mathrm{pH}$ and calcium-magnesium ratio decreased in soils proximal to the mine site.

\section{References}

[1] Shukla, M.K, Lal, R., Underwood , J. and Ebinger, M. 2004. Physical and hydrological characteristics of reclaimed mine soils in southeastern Ohio. Soil Sd. Soc Arn.J., 68:1352.1359.

[2] Rodrigue,J.A. and J.A.Burger.2004.Forest soil productivity of mined land in the Midwestern and Eastern Coalfield regions.Soil Sci. Soc .Am.J.,68:833-844.

[3] Thomas, K.A. and Sencindiver, J.C., Skollusem , J.G. and Gorman, J.M. 2000a. Soil horizon development on a mountain surface mine in southern vest Virginia Greenlands 30:41-52 Rodrigue, 3.A . and Burger , J.A. 2004 . Forest soil productivity of mined land in the Midwestern an $\mathrm{d}$ eastern coalfield regions. Soil Sci. Soc. Am. J., 68:833-844

[4] Gorman, J.M. and Sencindiver, J.C. 1999. Changes in minesoil physical properties over a mine year period. Proceeding of the Annual National meeting of the American society of surface mining and Reclamation at Scottsdale, Az, pp. 245-253.

[5] Haerring, K.C; Daniels, W.L. and Roberts, J.A.. 1993. Changes in mine soil properties resulting from overburden weathering J. Environ. Qual.

[6] Koose , A 2000 . Pedogenesis in the human environment. Proceedings of first International Conference on soil of Urban Industrial Traftic and mining Areas (SUTTOMA) at University of Essen, pp. 24 1-246.
[7] Khotchanin, K., Thanasuthipitak, P. and Thanasuthpipitak, T. 2010. characteristics of' trapiche blue sapphires from southern Vietnam. Chiang Mai J.Sci.. 39(1): 64- 73.

[8] Thurman, N.C. and Sencindiver, J.C.. 1986. Properties, classification and interpretation of minesoils at two sites in West Virginia. Soil Sci. Soc. Am. .1. 50:15 1-185:

[9] Taiz, L. and Zeiger, E 1991. Stress physiology. In: plant physiology, Benjamin cummings PubI. Co. California. Pp. 362-3 64 .

[10] [10] Bendfeldt, E.S; Burger, J.A. and Daniels, W.L.. 2001. Quality of amended mine soils after sixteen years. Soil Sci Soc. Am. J., 65:1736-1744.

[11] Onweremadu, E.U., Izuogu, O.P. and Akamigbo, E.O.R.. 2010. Aggregation and pedogenesis of seasonally inundated soils of a tropical watershed. Chiang Mai J.Sci, 37 (I): 74-84.

[12] Reich, P.F., Number, S.T. Alrnaraz, R.A. and Eswaran, H. 2001. Land resource stresses and desertification in Africa. Agro-Science, 2(2): 1-10.

[13] Onweremadu, E.U. 2008. Evaluating soil structure and hydraulic conductivity by land use in Nigeria. Soil Surv. Horiz; 49:6-11.

[14] Onweremadu, E.U., Izuogu, O.P. and Akamigbo, E.O.R.. 2010. Aggregation and pedogenesis of seasonally inundated soils of a tropical watershed. Chiang Mai J.Sci, 37 (I): 74-84.

[15] Orajaka, S.O. 1975. Geology. In: Ofornata, G.E.K. (ed.) Nigeria in maps: Eastern States. Ethiope Publishing House, Benin City. Pp. 5-7.

[16] Ofomata, G.E.K. 1975. Relief. In: Ofomata, G.E.K. (ed.) Nigeria in maps: Easterm States. Ethrope publishing House, Benin City. pp. 5-7.

[17] Monanu, P.C. 1975, Temperature and Sunshine. In: Ofornata, G.E.K. (ed.). Nigeria in maps: Eastern states. Ethiopic Publishing House, Benin city. pp. 16-1 8

[18] FAO (Food and Agriculture Organization). 2006. Guidelines for soil profile description. 3 editions, FAO Rome. 7Opp.

[19] Gee, G.W. and Or, D. 2002. Particle size analysis. In: Dane, J.H. and Topp, GC. (ed.) Methods of soil analysis, part4. physical methods. SSSA Book Senes Nos, ASA and SSSA, Madison, W.1. pp. 255-293.

[20] Grossman, R.B. and Reinsch, T.G. 2002. Bulk density and linear extensibility. In Dane, J.H. and top, G.C. (eds). Methods of soil analysis. Physical methods. Soil Sci. Soc. Am. Book Series, AsA and SSSA, W1.pp. 20 1-22

[21] Foth, H.D. 1984. Fundamentals of soil science. 7thi edition: John Wiley and Sons, New York. 435 pp.

[22] Watson, W.E. and Brown., J.R. 1998. pH, And lime requirement. In: Recommended chemical soil test procedures for the north central region North Central Regional Research Publ. 221, Missouri Agri. Exp. Stu, Colombia. Pp 13-16.

[23] Nelson, D.W. and Sommers, L.E. 1982. Total carbon, organic carbon and organic matter. In: page. A.L.; Miller RI-I. and Keeaey, D.R. (eds). Methods of soil analysis. 2uid ed. Agron. Monogr. ASA and SSSA, Madesion, Wl.pp. 539-579. 
[24] Brernner, J.M. 1996. Nitrogen-total. In: Sparks, D.L. (ed.) Methods of soil analysis, 2'ed:'Agrom-Monogr; ASAandSSSA; Madison;WI:Pp. 1085-1 12 I: -

[25] Olsen, S.R. and Sommers, LB. 1982. In: Page, A.L; Miller, R.H. and Keeney, DR. (eds). Methods of soil analysis, 2' ed. Agron. Monogr. ASA and SSSA. Madison, WI. pp. 403-430.

[26] Mclean, E.O. 1982. Soil $\mathrm{pH}$ and lime requirement. In: page, A.L., Miller, R.H. and Keeney, D.R. (eds) Methods of soil analysis. 2nd ed. Agron. Monogr. ASA and SSSA, Madison, WI.pp.199-234.

[27] Jackson, M.L. 1958. Soil chemical analysis. Prentice Hall Englewood cliffs Nev Jersey. 498 pp.

[28] Schafer, W.M., Nielsen, G.A. and Nettleton, W.D.. 1980. Minesoil genesis and morphology in a spoil chronosequence in Montana. Soil Sci. Soc. Am. J.. 44:802-807.

[29] Daniels, W. 1999. Creation and management of productive mine soils. Povell project Reclamation: Guidelines for surface —mined land in southwest Virginia 12Ipp.

[30] Thomas, K.A., Sencindiver, iC.. Skousen, J.G and Gorman, J.M.. 2000b. Soil horizon development on a mountaintop surface mine in southern West Virginia. http://www.wvu .edu/agexten/landrec/soilhori.htm.
[31] Sobek, A.A.,. Skousen, J.G and Fisher, S.E.. 2000. Chemical and physical properties of overburden and minesoils. pp. 77104. In: R.I. Barrihisel et al. (eds) Reclamation of drastically disturbed lands. Agron. Monogr. 41. ASA, CSSA and SSSA, Madison, WI

[32] Ahn, P.M. 1979. West African soils. Oxford Univ. Press, Oxford.Great Britain.332pp. Andrews, J.A., Johnson, J.E. . Torbert, J.L Burger, J.A. and Kelting. D.L.. 1998, Mine soil and soil properties associated with early height growth of eastern white pine, J. Environ. Qual., 27: 192-199 (Ahn. 1979).

[33] Landon. T.R. 1991. Booker tropical soil manual: A handbook of soil survey and agricultural land evaluation in the tropics and subtropics. Longrnan Scientific \& Technical, U.K. 474 pp.

[34] Jandi, R; Alewell, C. and C. Prietzel, C. 2004. Calcium loss in central European forest soils. Soil Sci Soc. Am. J., 68: 588595 .

[35] Landon. T.R. 1991. Booker tropical soil manual: A handbook of soil survey and agricultural land evaluation in the tropics and subtropics. Longrnan Scientific \& Technical, U.K. 474 pp.

[36] Kohler, M., von Wilpert, K. and Hildebrand. E.E. 2000. The soil skeleton as a source for the short term supply of base cations in forest soils of the Black Forest (Germany). Water, Air, Soil pollut; 122: 37-48. 